\title{
The economic impact of the upcoming EU emissions trading system on airlines and EU Member States-an empirical estimation
}

\author{
Martin Schaefer • Janina Scheelhaase • \\ Wolfgang Grimme $\cdot$ Sven Maertens
}

Received: 5 November 2009 / Accepted: 6 October 2010 /Published online: 10 November 2010

(C) The Author(s) 2010. This article is published with open access at Springerlink.com

\begin{abstract}
Purpose In February 2009, the European Union's (EU) Directive for the inclusion of aviation into the EU Emissions Trading Scheme (EU-ETS) for $\mathrm{CO}_{2}$-emissions came into force. From 2012 onwards, the EU-ETS will cover virtually all flights departing or arriving in the EU. As aircraft operators (i.e. airlines) will be required to hold emission allowances for all flights that are subject to the EU-ETS, the economical impacts of the system are currently being discussed. This paper aims at estimating and analysing the economical impact of the EU-ETS on the aviation sector in total, on selected groups of airlines and on the administering states.

Materials and methods This paper describes a simulation model for the economical impact of the EU-ETS. According to current plans, the initial allocation of emission allowances to airlines will be based on a benchmark which is calculated by dividing the $2004-2006 \mathrm{CO}_{2}$-emissions by the transport performance of the year 2010. The simulation model calculates $\mathrm{CO}_{2}$ emissions and transport performance
\end{abstract}

M. Schaefer

Institute of Propulsion Technology,

German Aerospace Center (DLR),

Linder Höhe,

Cologne, Germany

J. Scheelhaase $(\varangle) \cdot$ W. Grimme $\cdot$ S. Maertens Institute of Air Transport and Airport Research, German Aerospace Center (DLR),

Linder Höhe,

Cologne, Germany

e-mail: Janina.Scheelhaase@dlr.de of European aviation for the timeframe 2004-2012. The approach is based on flight schedules for passenger and cargo air traffic coupled to an aircraft performance module. By use of this model, the benchmark and hence the initial allocation of emission allowances to airlines can be estimated. Using assumptions on the development of the $\mathrm{CO}_{2}$ allowance price, the economical impacts of the EUETS can be discussed.

Results and discussion The economic effects of the upcoming EU-ETS on the aviation sector in total, on selected groups of airlines and on the administering states are analysed and discussed. It is shown that additional to the freely allocated allowances, nearly all aircraft operators need to purchase allowances for about one third of their emissions in 2012. The total cost for the aviation sector is expected to be in the range between 1.9 and 3.0 billion $€$ in 2012. Certain airline groups and administering EU States will be affected very differently by the new EU legislation. It is shown that particularly European network carriers will be affected by a competitive disadvantage compared to non-EU airlines.

Keywords Environment, aircraft emissions · Airline competition - Air transport policy . Climate change .

Environmental economics - EU emissions trading scheme . European Commission

\section{Introduction}

In July 2008, the European Council and the European Parliament agreed to include international aviation into the existing EU Emissions Trading Scheme for the limitation of 
$\mathrm{CO}_{2}$-emissions. The Directive came into force in February 2009 [8]. Aircraft operators will be obliged to surrender allowances for virtually all commercial flights into, within or out of the EU from 2012 onwards. The EU-ETS will affect both European and third-country airlines. The European Commission justifies this approach by stating that a distortion of competition in the international airline sector needs to be avoided to the most possible extent and that this approach will improve the environmental effectiveness of the scheme. Several non-EU states, however, have expressed doubts regarding the environmental effectiveness of the EU-ETS and whether the EU approach conforms to international law.

A number of economic studies on these controversial issues have been conducted lately, e. g. by Faber, van der Vreede and Lee [13], Forsyth, Dwyer and Spurr [15], Boon et al. [5], Forsyth [14] as well as Scheelhaase, Grimme and Schaefer [25]. These studies focus on different aspects of the topic such as the method of initial allocation of allowances, the impacts on tourism as well as the economic impacts on different airline types. A meta-study by Anger and Köhler [4] reviews the impact assessments of the EU-ETS as developed in 9 different studies published between 2005 and 2009. It is found that some of the assumptions and results differ considerably, such as assumptions with regard to the cost pass-through rates used in the estimations. Other assumptions, in contrast, are similar in all of the reviewed studies, such as the assumed span for future allowance prices. Two major points of critic Anger and Köhler are bringing forward are an over-simplification of the calculations applied in the reviewed studies, and that some of the studies are based on assumptions different to the eventual content of the directive which came into force in 2009.

This paper analyses how the inclusion of aviation into the EU-ETS will affect the air transport sector both economically and ecologically. In order to target these questions, an empirical simulation model was developed, which goes far more into detail than those applied in previous studies. The model is based on global flight schedules of the Official Airline Guide (OAG) supplemented by a DLR developed flight plan for cargo and integrator airlines. All flight movements are simulated by DLR aircraft performance software in order to calculate the specific fuel consumption and $\mathrm{CO}_{2}$ emissions. By employing this model, current and future $\mathrm{CO}_{2}$-emissions and transport performance data of European aviation will be estimated. Furthermore, the economic effects of the upcoming EU-ETS on both the aviation sector and individual airlines will be estimated and discussed. In contrast to earlier studies, our model's assumptions are in line with the contents of the final directive.

This paper is organized as follows: Initially, an overview of the EU legislation on emissions trading and aviation for the years 2012 and beyond is provided (chapter 2). Subsequently, our modelling approach (chapters 3 and 4) and the main economic and ecologic effects for the aviation sector as well as for the EU member States are presented and discussed (chapter 5). Finally, conclusions about the impacts on costs, airfares and competition within the aviation sector are drawn (chapter 6).

\section{Political background}

The EU Directive contains the following provisions for the inclusion of aviation into the existing EU-ETS:

- Virtually all flights departing from or arriving at EU airports will be covered from 2012 onwards. Domestic flights will be subject to the same rules as international air traffic. If any non-EU country introduced alternative measures with similar climate protecting effects, the geographical scope of the ETS could be modified such that flights arriving from or departing for this particular country are excluded from the scheme.

- Aircraft operators will be obliged to hold and surrender allowances for $\mathrm{CO}_{2}$-emissions. Allowances are required for flights by fixed-wing aircraft with a maximum take-off mass of 5,700 kg or above. Flights performed under visual flight rules and rescue flights (amongst a number of other exceptions) are excluded from the scheme.

- Exemptions will also be granted for flights performed in the framework of public service obligations (PSO) on routes within outermost regions or on PSO routes where the capacity offered does not exceed 30,000 seats per year. Also excluded from the EU-ETS will be flights performed by a commercial air transport operator operating either fewer than 243 flights per four-month period for three consecutive four-month periods (so-called 'de minimis' clause) or flights with total $\mathrm{CO}_{2}$-emissions lower than 10,000 tonnes per year. The 'de minimis' clause was added in order to reduce administrative costs for operators with a low number of flights to and from Europe.

- Regulations for emission monitoring and reporting will take effect in 2010 while an emission cap for all aircraft operators will be introduced in 2012.

- In the first year of the inclusion of aviation into the EUETS, the total quantity of allowances to be allocated to aircraft operators shall be equivalent to $97 \%$ of the historical aviation emissions (so-called overall "cap"). The historical aviation emissions will be calculated on the basis of the average total emissions of the years 2004-2006 borne by all aircraft operators taking part in the scheme. The historical emissions will be defined by the European Commission with technical assistance from Eurocontrol. 
- Initially, allowances will be allocated to aircraft operators mostly free of charge. In the year 2012, $85 \%$ of the allowances shall be allocated for free. The method of allocating allowances to aircraft operators will be harmonised within the European Union.

- The total number of allowances allocated to each aircraft operator will be determined by a benchmark which is calculated in three consecutive steps: First, the share of auctioned allowances is subtracted from the overall "cap". Second, the remaining $\mathrm{CO}_{2}$-emissions will be divided by the sum of verified tonne-kilometre data for flights falling under the geographical scope of the EU-ETS in the monitoring year 2010, as reported by all participating aircraft operators. Third, the specific amount of allowances each operator receives is calculated by multiplying the respective individual tonne-kilometre value of the monitoring year with the benchmark. Each operator's revenue tonne-kilometres are calculated by multiplying the mission distance (great-circle-distance plus an additional fixed surcharge of $95 \mathrm{~km}$ ) by the payload transported (cargo, mail and passengers). For the calculation of the performed tonne-kilometres, each passenger including baggage is assigned a value of $100 \mathrm{~kg}$.

- In 2012, allowances allocated to aircraft operators will be valid within the aviation sector only. However, additional permits can be purchased from other sectors or from the project based Kyoto instruments "Joint Implementation" and "Clean Development Mechanism". Allowances not used in 2012 can be 'banked' to the third trading period of the EU-ETS (2013-2020).

- Allowances not allocated free of charge (15\%) will be auctioned by the Member States. The revenues should be used to tackle climate change in the EU and third countries, inter alia, to reduce greenhouse gas emissions, to adapt to the impacts of climate change or to fund research and development in these fields.

The EU Directive for the period 2013-2020 [8], as it was agreed in December 2008, aims at improving and extending the greenhouse gas emission allowance trading system of the Community. Due to its broader nature, it adopts regulations for all sectors included in the system and very few aviation-specific rules. It is understood that most of the regulations for the first year of the inclusion of aviation into the EU-ETS which are described above will be further applied. However, the total quantity of emission allowances to be allocated to aircraft operators shall then be equivalent to only $95 \%$ of the historical aviation emissions, multiplied by the number of years in the eight-year period. The use of the project based Kyoto instruments "Joint Implementation" and "Clean Development Mechanism" will be lowered significantly for aircraft operators. In the period
2013 until 2020, aircraft operators may use emission permits from "Joint Implementation" and "Clean Development Mechanism" only up to $1.5 \%$ of the amount of allowances they are required to surrender per year (in 2012: $15 \%$ ). However, purchasing emissions permits from stationary sources is possible without limitations.

\section{Modelling air transport's $\mathrm{CO}_{2}$-emissions and transport performance}

Modelling the upcoming EU-ETS requires an estimation of both European aviation's fuel consumption (and hence $\mathrm{CO}_{2}$-emissions) and the corresponding transport performance measured in tonne-kilometres. This is not an easy task since no detailed and publicly available statistics regarding $\mathrm{CO}_{2}$-emissions of the European air transport sector exist to date. The approach chosen for our study combines world-wide flight schedules with an aircraft performance software. OAG flight schedules for the years 2004-2008 were supplemented by an additional flight plan for all-cargo flights. Schedules from OAG were selected since information on actual aircraft movements from filed flight plans or radar data collected by Eurocontrol are not publicly available. Flights from and to the European Union (EU27 plus outermost regions) were identified by evaluating the origin and destination country codes. Although some charter services operated on behalf of tour operators and ad-hoc charters are not included in OAG, we regard OAG data as a good proxy for the air transport volume in the passenger sector considering the following aspects:

- According to DLR calculations based on EUROSTAT figures for 2007, non-scheduled flights account for about $12 \%$ of all IFR passenger flights [11]. With OAG data containing all scheduled and some of the unscheduled air traffic, the percentage of non-OAG passenger flights should be smaller than this figure.

- A large percentage of these non-scheduled flights can supposed to be operations exempted from the EU-ETS, e.g. flights with aircraft of less than $5,700 \mathrm{~kg}$ maximum take-off mass or flights falling under the 'de minimis' clause.

- As some flights are typically cancelled, OAG will slightly overestimate the real traffic volume from scheduled services. This overestimation, in turn, may compensate for the unscheduled passenger flights not included in OAG.

For the air cargo market, in contrast, OAG data availability is less satisfying, as most integrator services and all ad-hoc services are missing. In order to improve the data availability in the cargo sector, we have compiled a flight plan comprising a presumably large part of the 
non-OAG all-cargo flights from and to Europe. This additional schedule mainly consists of double-checked flight information found in airport timetables, in press releases of air cargo companies and on websites run by aviation enthusiasts.

The aircraft performance software VarMission developed at the DLR Institute of Propulsion Technology was employed to calculate fuel consumption and $\mathrm{CO}_{2}$-emissions of each flight in the flight schedules. VarMission is written in Microsoft Visual Basic for Applications (VBA). A Microsoft Access database contains aircraft and engine data. For this study, the tool uses aircraft models from the EUROCONTROL Base of Aircraft Data (BADA) [10]. This database contains information on 91 aircraft types including most large airliners. Aircraft for which no data are available can be represented by models with similar characteristics. In order to speed up the calculation process, interpolation tables produced by VarMission for all aircraft models were used in this study, which contain precalculated flight mission protocols for different ranges and payloads as well as the fuel burn along these profiles. Using these look-up tables in combination with interpolation methods, fuel burn and emissions can be calculated for each flight in the flight schedules. Fuel burn and emissions calculations based on BADA data have a history of being used for global emission inventories (e. g. the FAA's SAGE inventories) and can be considered a standard for such applications [12].

The VarMission software considers taxiing on the ground, take-off, climb, cruise and descent flight phases. The fuel consumption of a flight is calculated iteratively, reducing the aircraft mass (due to fuel burn) in each calculation step. Since the take-off mass of a flight is initially unknown, the program performs the calculation process "backwards", i.e. starting with the aircraft's empty weight plus payload, considering reserve fuel quantities and analysing all flight phases in reverse order. The flight distance of each flight was estimated by applying an empirical "inefficiency" factor to the great-circle distance between origin and destination airports. The factor ranges from 1.06 on short-range flights (up to $500 \mathrm{~km}$ ) to around 1.03 on long-range missions.

The payload assumed for each flight could be calculated based on the aircraft's maximum payload multiplied by a flight's weight load factor. While flight schedules contain information on payload capacity available on each flight, actual passenger numbers and the (total) payload transported had to be estimated. For this purpose, each flight in the schedules was supplemented by load factor data from different sources. The sources used to determine both seat load factors and overall weight load factors include the ICAO Traffic by Flight Stage databank and ICAO's Air Carrier statistics [19]. By combining such data with the available seats and payload capacities from the schedules, an estimation of the relevant transport performance for the years 2004-2008 could be provided.

As the EU-ETS will be introduced in 2012, forecast flight schedules were produced based on the latest available scheduled data. Given the current economic situation, no traffic growth was assumed between 2008 and 2010. For the years 2010-2012, on the other hand, regional growth factors derived from common manufacturers' forecasts were applied to the base year flight schedules in order to produce a forecast up to the year 2012. The introduction of more fuel-efficient aircraft, potential improvements in the field of Air Traffic Management and a further increase in terms of load factors were considered by assuming a $1 \%$ efficiency improvement per year resulting in a corresponding reduction of fuel-consumption and emissions per tonne-kilometre. This way, a reliable and best possible estimation of traffic volumes and $\mathrm{CO}_{2}$-emissions of European flight operations up to the year 2012 could be performed.

Forecasts of traffic volumes and $\mathrm{CO}_{2}$-emissions were created for this study covering the years 2010 to 2012. In our forecast of traffic volumes we are assuming that recent market developments like heavily fluctuating oil prices, as well as the costs for participating in the EU-ETS, will have no sustainable negative impact on future aviation growth in the medium and long-term. This is because a number of studies indicate that airlines will be able to pass on, to a large extent, the additional costs to the customers, of whom many are not very price sensitive (see e.g. [6], [26]). However, we are taking into account the 2008/2009 worldwide recession. We assume a recovery point in the second half of 2009 , leading to 2010 traffic volumes equal to those of 2008 before the recession (i.e. until August). From September 2010 onwards the forecast is based on our data for the last 12 months before the recession in combination with average annual growth rates derived from the most common manufacturers' forecasts, i.e. the Airbus Global Market Forecast [1], Boeing's Current Market Outlook [3] and Rolls-Royce's Market Outlook [24]. Additionally, the forecast of the ICAO Forecast and Economic Subgroup (FESG) was analysed [18]. Each of these forecasts provides average annual growth rates for the transport performance on either region or country pair level up to 20 years into the future. For our model, an average forecast was created, using the mean growth rate of all four market forecasts for each region or country pair. The projected growth for air traffic from and to Europe in terms of passenger-kilometres lies between $3.4 \%$ per annum (domestic flights within Western Europe) and 6.0\% per annum (flights between South East Asia and Western Europe). In the cargo market, forecasted growth rates are typically higher and vary between $4.15 \%$ (within Europe) 
and $7.45 \%$ (China-Europe). A sensitivity analysis showed that the use of just one of the original forecasts mentioned above would not have resulted in significantly different results on a global scale.

For the development of the $\mathrm{CO}_{2}$-Emissions, however, a factor of $1 \%$ per year for autonomous efficiency gains is included in the forecast. This value is based on long-term observations of the air transport system and correlates with the fuel efficiency target of IATA for the years 2000 to 2010 [16]. The factor represents the efficiency gains that will be achieved in the air transport system by e.g. optimisation of operational procedures, air traffic control or the introduction of larger, more modern and more fuelefficient aircraft.

\section{Modelling the upcoming EU-emission trading system}

\subsection{Overview}

Given the world-wide flight movements, the transport performance in tonne-kilometres and $\mathrm{CO}_{2}$-emissions, core elements of the upcoming EU-ETS can be modelled. Our modelling approach is based on the Directive 2008/101/ EC [9]. The regional scope assumed for the emissions trading scheme comprises all flights from and to the European Union (plus outermost regions). While the participation of EFTA (European Free Trade Association) states seems likely, flights within and between Norway, Switzerland, Iceland and non-EU-countries are not included in our model.

The 'de minimis' clause (see chapter 2) was incorporated in the model and operators with less than $10,000 \mathrm{t} \mathrm{CO}_{2}$ emitted per year or fewer than 729 flights per year in 2010 were identified. The results of the model show that none of the airlines contained in the OAG flight schedules and operating to/from the $\mathrm{EU}$ emits less than $10,000 \mathrm{t} \mathrm{CO}_{2}$ per year. However, 95 operators were identified with less than 729 flights per year, representing about $1 \%$ of the total emissions and $2 \%$ of the revenue tonne-kilometres according to the reporting standards of the EU-ETS. For simplification, further checks for public service obligation (PSO) routes or routes within the outermost regions were omitted, as both the emissions and RTKs of these flights are negligible with less than $0.1 \%$ of the total RTKs performed on flights to or from the EU. Actually, most PSO routes in the EU will require emission allowances, as the exclusion criterion of 30,000 seats offered annually (which corresponds to only 82 seats per day) is exceeded by most of them.

The most important elements of modelling the economic effects of the upcoming EU-ETS for aviation are the initial allocation of $\mathrm{CO}_{2}$-emission allowances and the future development of $\mathrm{CO}_{2}$ allowance prices.

\subsection{Initial allocation of $\mathrm{CO}_{2}$-emission allowances}

The first step in modelling the initial allocation of the upcoming EU-ETS is the calculation of the total amount of emission allowances available to the aviation sector in the first trading period in 2012. The total constitutes $97 \%$ of the average 2004-2006 historical aviation emissions:

Total Allowances $2012=0.97 \times$ Historical Emissions $2004-2006$

As $15 \%$ of the total allowances will be auctioned, the number of allowances allocated to the operators free of charge will be calculated as follows:

Free Allowances $2012=0.85 \times$ Total Allowances $_{2012}$

For the calculation of the benchmark, which will be used for the free allocation of allowances to each individual operator in 2012, the total allowances allocated free of charge will be divided by the revenue tonne-kilometres reported for the year 2010:

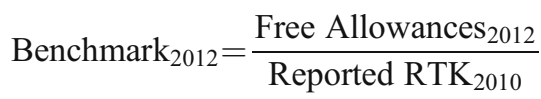

In compliance with the EU Directive [9], a passenger weight of $100 \mathrm{~kg}$ and an addition of $95 \mathrm{~km}$ to the greatcircle distance of each flight need to be considered when calculating the reported RTKs.

4.3 Development of the $\mathrm{CO}_{2}$-emission allowances price until 2020

The prices of EU Allowances (EUAs), Certified Emission Reductions (CERs) from Kyoto-based Clean Development Mechanism projects and Emission Reduction Units (ERUs) from Kyoto-based Joint Implementation projects and the future development of these prices are important factors for the economic impact of the EU-ETS on the aviation sector. Our assumptions on the carbon price in the years 2012 and 2020 are based on findings in the relevant literature ([6], [20], [21], [22] and [26]) and on the following thoughts:

1. The carbon price is directly determined by the abatement costs for an additional unit of $\mathrm{CO}_{2}$. This is because emitters can either abate $\mathrm{CO}_{2}$ or buy $\mathrm{CO}_{2}$ permits to comply with their individual reduction target in an ETS. In the course of time, $\mathrm{CO}_{2}$ abatement in the EU will become more costly due to the tightening of the EU-ETS overall cap. A number of researchers believe that the ambitious target set by the European Commission to reduce $\mathrm{CO}_{2}$-emissions by 2020 can 
only be realised by the deployment of CCS coal plants (coal plants that are equipped with carbon capture and storage technology) and renewable energy sources. In the medium term it could become viable at prices of 35 $€ / t \mathrm{CO}_{2}$ to $40 € / \mathrm{tCO}_{2}$ [21]. For this reason, we assume a maximum price of $40 €$ per tonne of $\mathrm{CO}_{2}$ in the period 2008-2012.

2. The possibility of 'banking' unused allowances from one trading period to another will ensure a relatively common EUA price across both trading periods (20082020).

3. The inclusion of the aviation sector as well as the aluminium, petrochemical and ammonia industry into the EU-ETS starting from the year 2012 will not raise EUA prices significantly. This was shown by a number of studies, for instance by [20] and [6]. But the progressively rising level of auctioned allowances and the ambitious overall greenhouse gas cap will lead to rising prices for EUAs until 2020.

4. The prices for CERs and ERUs will mirror the EUA price developments because the prices for these projectbased permits are in principle also determined by the factors explained above. Due to a higher risk of nondelivery related to CERs and ERUs (compared to EUAs), CER/ERU prices are currently a bit lower than EUA prices. We believe that this spread between the prices for both kinds of permits, which at present amounts to about $4 €$, will persist in the future.

On this basis, we assume price ranges for EUAs and CERs/ERUs for the years 2008-2012 and 2013-2020 as shown in Table 1. Taking into account the rather high levels of uncertainty of these future developments, we assume a price spread for each trading period and permit type. In order to diminish complexity, in this paper our estimations only take into account the assumed prices for EUAs.

\subsection{Limitations and assumptions in our model}

As it is the case with every model, our model contains several simplifications compared to reality. The following paragraph discusses some of the implications of the assumptions the model is based on.

In principle, several scenarios concerning the passthrough of acquisition costs and opportunity costs of freely allocated allowances can be considered. In case a partial or full pass through occurs, it is reasonable to assume that a demand reaction will follow, depending on the extent of the price increase and the price elasticity of demand. In the model presented herein, we assume no change in passenger demand or airline supply in reaction to the EU-ETS. This is due to the fact that reliable data on the price elasticity of demand for air travel does not exist for this issue. This implies the assumption that none of the costs for the EUETS will be passed through to passengers and shippers of air cargo. Furthermore, our forecasting model increases frequencies on existing routes, but does not take into account potential impacts of the EU-ETS on airline strategies concerning aircraft size, frequencies or the discontinuation of existing routes. As the results of our model presented in this paper are focused on the assessment of cost impacts for the airline industry in the rather shortterm until 2012, we are not predicting long-term changes in market, fleet or network structures.

\section{Results}

\subsection{World-wide transport performance}

The modelled $\mathrm{CO}_{2}$-emissions and the transport performance for flights to and from the European Union are not directly comparable to any publicly available data. However, as our model covers not only flights to and from the EU but the global air transport system, it is possible to compare the results for the world-wide transport performance with statistics published by ICAO. It should be noted, however, that the integrator and all-cargo services considered in our model do not cover all such flights within and between countries outside the EU, which are likely to be included in the ICAO statistics. Table 2 compares model results and ICAO data for world-wide scheduled air traffic.

It can be observed that, on a global level, the goodness of fit between modelled transport performance and ICAO data is within a range of $5 \%$. Generally, it seems that the model overestimates available seat-kilometres (ASK) and revenue passenger-kilometres (RPK) slightly compared to ICAO statistics. The total tonne-kilometres (RTK) calculated are very close to the reference, but given the incomplete coverage of all-cargo flights in our model, this seems to be consistent with the slightly overestimated ASKs and RPKs. Looking at the reference data from another angle, it is also questionable whether data published by ICAO can be considered as $100 \%$ accurate. This is because ICAO is dependent on data delivered by its contracting states as well as on data availability. As a result, the quality of ICAO data is likely to be rather heterogeneous.

Data availability for a validation on a more detailed geographical level is problematic. While in the United States a very accurate set of air transport data is provided by the Bureau of Transportation Statistics, airline-specific information on flown aircraft kilometres or revenue ton kilometres is not available for other world traffic regions. Based on the data from the United States we conclude that also on a more detailed geographical level, our estimations show a very good fit compared to published data. On 
Table 1 Assumptions on the EUA and CER/ERU price development in the future

DLR estimation

\begin{tabular}{lllll}
\hline Permit type & EUAs & & CERs/ERUs \\
\hline Trading period & $2008-2012$ & $2013-2020$ & $2008-2012$ & $2013-2020$ \\
$€$ per tonne $\mathrm{CO}_{2}$ & $25-40$ & $40-55$ & $21-37$ & $37-52$ \\
\hline
\end{tabular}

average, the accuracy for modelled passenger kilometres for US airlines shows a slight overestimation of around $+1 \%$.

5.2 Transport performance and $\mathrm{CO}_{2}$-emissions for flights to/from the EU \& allowances available to aircraft operators

The model results regarding transport performance and $\mathrm{CO}_{2}$-emissions of the worldwide air traffic as well as for flights from and to EU airports are shown in Fig. 1. The $\mathrm{CO}_{2}$-emissions of flights from and to EU airports and the corresponding transport performance are summarized in Table 3. The average yearly emissions from 2004 to 2006 amount to 183.3 million tonnes. Considering the 'de minimis' clause and subtracting emissions of operators with less than 729 flights per year, the historical $\mathrm{CO}_{2}$ emissions subject to the EU-ETS are estimated at 180.9 million tonnes. It is worth noting that, through the EU-ETS, roughly one third of global aviation's $\mathrm{CO}_{2}$-emissions will be subject to a regulation.

According to our model, the aviation sector will receive 175.5 million allowances for the emission of $\mathrm{CO}_{2}$ in the year 2012, since the owner of one allowance has the right to emit one tonne of $\mathrm{CO}_{2} .85 \%$ of all allowances, i.e. 149.2 million will be allocated free of charge while the remaining 15\% (26.3 million allowances) will be auctioned. Considering the estimated range for the future price of allowances ( $25 €-40 €$ ), governments of the EU Member States will receive between 660 million and 1050 million $€$ as a revenue from the auctioning of allowances.
It is worth noting that our model seems to underestimate aviations' emissions under the EU ETS in the year 2008 by $5 \%$ according to unofficial figures presented by the European Commission in May 2010 [25]. This slight underestimation may have numerous reasons but can only be analyzed when the highly political EU ETS cap will be officially published. Currently, its publication is postponed until 2011.

\subsection{Benchmark calculation}

For 2010, we estimate the transport performance of all flights from and to EU airports at 229,196 million tonnekilometres flown (see Table 4). This translates into 254,400 million tonne-kilometres according to the reporting standards of the EU-ETS. The difference between these two values is the fixed surcharge of $95 \mathrm{~km}$ to each flight's greatcircle distance allowing for any route inefficiencies and the uniform assumption of $100 \mathrm{~kg}$ per passenger for the conversion of passenger kilometres into tonne-kilometres.

Carriers operating less than 729 flights per year in the EU will not be obliged to participate in the EU-ETS. As a consequence, their transport performance will have to be excluded from the calculation of the benchmark. In the year 2010, this applies to 95 operators with 5,166 million reported tonne-kilometres, representing approximately $2 \%$ of the total tonne-kilometres of all flights from and to EU airports. The benchmark, calculated by dividing the amount of freely allocated allowances by the tonne-kilometres reported for the year 2010 is estimated by our model at $0.60 \mathrm{~kg} \mathrm{CO}_{2}$ per RTK.
Table 2 Comparison of selected model results with ICAO data for world-wide scheduled traffic

a assuming a passenger weight of
$90 \mathrm{~kg}$
DLR model results; ICAO data
from [17] and [2]

\begin{tabular}{llll}
\hline Year & Kilometres flown in million (modelled) & Kilometres flown in million (ICAO) & Delta \\
\hline 2004 & 30,103 & 29,163 & $3.2 \%$ \\
2005 & 32,362 & 30,862 & $4.9 \%$ \\
2006 & 33,541 & 32,137 & $4.4 \%$ \\
Year & ASK in billion (modelled) & ASK in billion (ICAO) \\
2004 & 4866.1 & 4704.7 & Delta \\
2005 & 5209.1 & 4975.9 & $3.4 \%$ \\
2006 & 5444.1 & 5197.3 & $4.7 \%$ \\
Year & RPK in billion (modelled) & RPK in billion (ICAO) \\
2004 & 3565.3 & 3445.3 & $4.7 \%$ \\
2005 & 3867.7 & 3721.7 & Delta \\
2006 & 4107.6 & 3940.6 & $3.5 \%$ \\
Year & RTK in million (modelled) & $3.9 \%$ \\
2004 & 459,598 & RTK in million (ICAO) & $4.2 \%$ \\
2005 & 500,464 & 458,910 & Delta \\
2006 & 516,998 & 487,860 & $0.1 \%$ \\
\hline
\end{tabular}




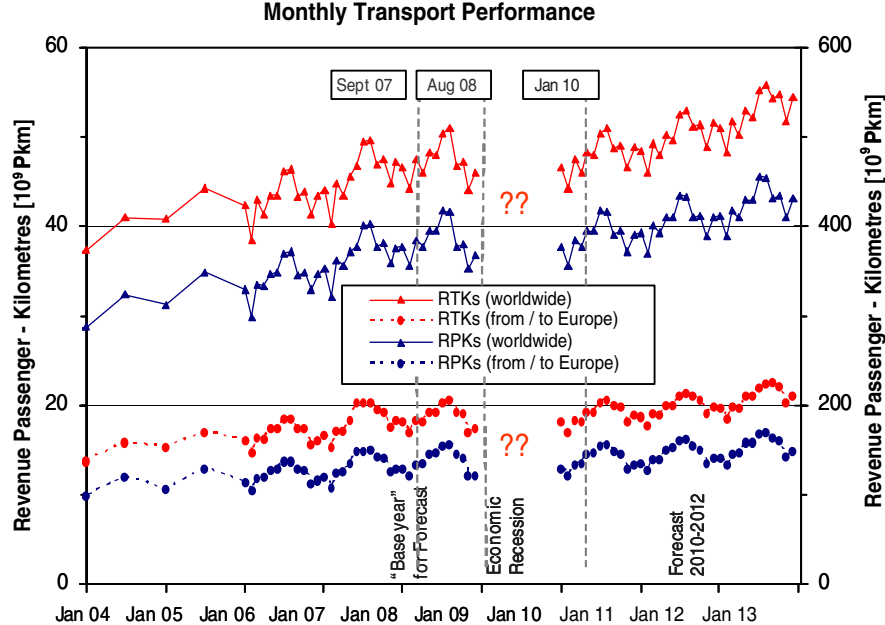

Fig. 1 Historical and forecasted transport performance and $\mathrm{CO}_{2}$ emissions (Transport performance assumes a passenger weight of $90 \mathrm{~kg}$; The period of time not modelled is marked by "??"). Source:

5.4 Freely allocated allowances vs. emissions in 2012 and acquisition costs for the aviation industry

An important parameter for estimating the costs of the EUETS for the aviation sector is the difference between the number of allowances allocated for free and the actually needed allowances for the first trading period. By applying our forecasting method, we estimate that the $\mathrm{CO}_{2}$-emissions of flights to and from airports in the EU will amount to a total of about 226.4 million tonnes in 2012. Considering the 'de minimis' clause and excluding operators with less than 729 flights per year, emissions of 223.6 million tonnes of $\mathrm{CO}_{2}$ will be subject to the EU-ETS.

With 149.2 million allowances allocated for free (see above), airlines will need to buy allowances for about 74.4 million tonnes of $\mathrm{CO}_{2}$-emissions. Taking into account the estimated price span of $25 €$ to $40 €$ for allowances, the cost for the acquisition of allowances will be between 1.9 and 3.0 billion $€$ for the entire aviation sector subject to the EUETS (in 2012). The results also show that $\mathrm{CO}_{2}$ allowances for about 48.1 million tonnes will have to be purchased by

Table 3 Historical transport performance and $\mathrm{CO}_{2}$-emissions of flights to/from the EU

\begin{tabular}{lll}
\hline Year & $\begin{array}{l}\text { RTK in million } \\
(\text { modelled) }\end{array}$ & $\begin{array}{l}\mathrm{CO}_{2} \text {-Emissions in million tonnes } \\
\text { (modelled) }\end{array}$ \\
\hline 2004 & 175,214 & 171.5 \\
2005 & 193,209 & 185.7 \\
2006 & 202,600 & 192.7 \\
\hline
\end{tabular}

a assuming a passenger weight of $90 \mathrm{~kg}$

DLR model results

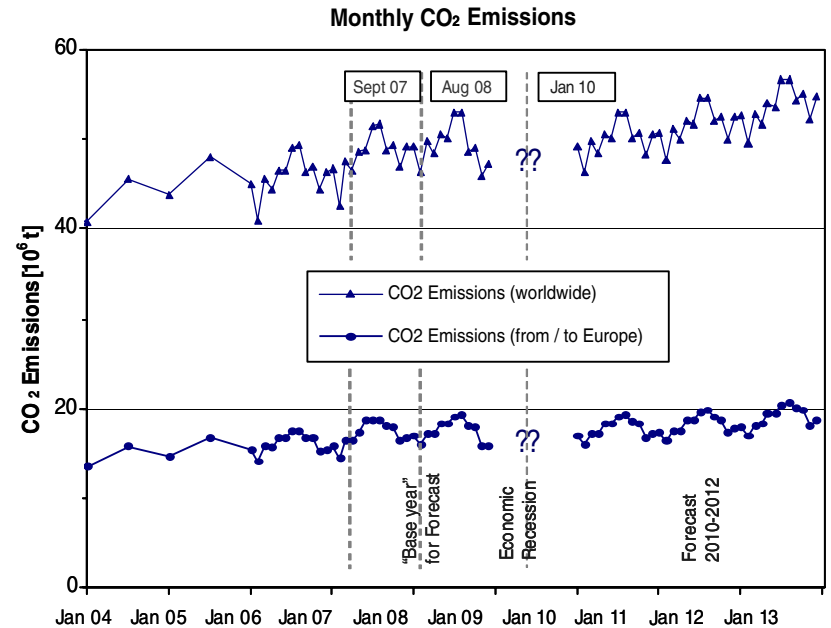

DLR model results based on OAG data [23] supplemented by allcargo services from and to Europe

aircraft operators from other sectors, as only 175.5 million new allowances will be available to the aviation sector on the basis of Directive 2008/101/EC.

\subsection{Comparison of acquisition costs for different} groups of airlines

As the forecast of individual airlines' future emissions is associated with rather large uncertainty, for the following analysis we focus on groups of airlines, clustered by their geographical origins and business models.

Table 5 shows forecasted $\mathrm{CO}_{2}$-emissions, the estimated amount of allowances allocated for free and the potential acquisition costs for three groups of airlines. The first group (10 largest EU network carriers) contains the EU-based network carriers with the largest transport performance measured in RTK, i.e. Lufthansa, British Airways, Air France, KLM, Iberia, Virgin Atlantic, Alitalia, SAS, TAP and Finnair. The second group (10 largest non-EU network carriers) consists of Singapore Airlines, American Airlines, Emirates, United Airlines, Delta Air Lines, Cathay Pacific,

Table 4 Forecasted transport performance and $\mathrm{CO}_{2}$-emissions of flights to/from the EU

\begin{tabular}{lll}
\hline Year & $\begin{array}{l}\text { RTK in million } \\
\text { (modelled) }\end{array}$ & $\begin{array}{l}\mathrm{CO}_{2} \text {-Emissions in million tonnes } \\
\text { (modelled) }\end{array}$ \\
\hline 2008 & 224,750 & 208.9 \\
2010 & 229,196 & 211.6 \\
2012 & 251,215 & 226.4 \\
\hline
\end{tabular}

a assuming a passenger weight of $90 \mathrm{~kg}$

Source: DLR model results 
Table 5 Comparison of initial allocation, forecasted emissions and acquisition costs for different airline groups

\begin{tabular}{llll}
\hline & $\begin{array}{l}\text { 10 largest } \\
\text { EU } \\
\text { network } \\
\text { carriers }\end{array}$ & $\begin{array}{l}\text { 10 largest } \\
\text { non-EU net- } \\
\text { work car- } \\
\text { riers }\end{array}$ & $\begin{array}{l}\text { 10 largest EU } \\
\text { low cost and } \\
\text { charter carriers }\end{array}$ \\
\hline $\begin{array}{l}\text { Free allocation of } \\
\text { EU-allowances in } \\
\text { Mt for 2012 }\end{array}$ & 60.8 & 24.0 & 12.4 \\
$\begin{array}{l}\text { Forecasted } \mathrm{CO}_{2^{-}} \\
\text {emissions for } 2012 \\
\text { in Mt }\end{array}$ & 93.0 & 31.8 & 18.4 \\
$\begin{array}{l}\text { Percentage of free } \\
\text { allocation }\end{array}$ & 65.4 & 75.6 & 67.5 \\
$\begin{array}{l}\text { EU allowances to be } \\
\text { acquired in Mt }\end{array}$ & 32.2 & 7.8 & 6.0 \\
$\begin{array}{l}\text { Acquisition cost for } \\
\text { additional } \\
\text { allowances }(25 € \\
\text { per allowance) in } \\
\text { million } €\end{array}$ & 805.3 & 193.9 & 149.7 \\
$\begin{array}{l}\text { Acquisition cost for } \\
\text { additional } \\
\text { allowances }(40 € \\
\text { per allowance) in } \\
\text { million } €\end{array}$ & 1288.5 & 310.2 & 239.5 \\
\hline
\end{tabular}

DLR model results

Continental, Thai, Korean Air and JAL. The third group consists of the ten largest EU-based low cost and charter carriers, which are Ryanair, easyJet, Air Berlin, Condor, LTU, TUIfly, Corsair, Clickair and Vueling.

Our model confirms earlier findings by the authors [25] that EU-based network carriers will be affected by a competitive disadvantage compared to their non-EU-based counterparts: Table 5 shows that the percentage of allowances allocated for free compared to the allowances required for the airlines' operations remains at a significantly lower level for EU-based network carriers than for non-EU carriers. This can be explained by the fact that EUbased carriers operate their feeder network under the ETS, while non-EU-based carriers operate only long-haul flights with comparably lower specific emissions under the ETS.

The percentage of freely allocated allowances for low cost and charter carriers (LCC) is in between the corresponding percentages for EU-based and non-EU-based network carriers. While most low cost routes are relatively short, such airlines operate at high seat densities, high passenger load factors and with modern aircraft, therefore achieving a relatively high percentage of free allocation. However, as we assume the growth of the LCCs to be in line with overall market growth rates, a higher growth of traffic and emissions could effectively result in a lower percentage of free allocation and, consequently, higher acquisition costs.
5.6 Revenues generated from the auctioning of allowances per EU Member State

As mentioned earlier, $15 \%$ of the allowances created for the aviation industry will be auctioned by the EU Member States in the year 2012. In order to reduce the administrative burden on aircraft operators and EU Member States, Directive 2003/87/EC provides for one Member State to be responsible for each aircraft operator. Article 18a of the Directive contains the provisions governing the assignment of each aircraft operator to its administering Member State. The administering Member State in respect of an aircraft operator shall be:

(a) in the case of an aircraft operator with a valid operating license granted by a Member State, the Member State which granted the operating license in respect of that aircraft operator; and

(b) in all other cases, the Member State with the greatest estimated attributed aviation emissions from flights performed by that aircraft operator in the base year.

In August 2009, the European Commission published the official list of aircraft operators and their administering Member StateS [7]. This list is based on data provided by Eurocontrol using records of flight plans. According to Article $3 \mathrm{~d}$ of the Directive, the number of allowances to be auctioned by each Member State shall be proportionate to its share of the total attributed aviation emissions for all Member States for the reference year reported (2010). This provision determines the amount of revenues generated from the auctioning of allowances per Member State. Therefore it may have significant financial impacts. Unfortunately, it allows for different interpretations. Upon request, the German Designated National Authority for administering the EU-ETS (DEHSt) clarified that the allowances for auctioning shall be allocated to the administering Member State according to the respective share of the 2010 emissions of the airlines administered. In contrast, an allocation of allowances to the administering Member State according to the attributable share of the 2010 emissions seems also to be in the scope of the provision of Article 3d of the Directive. By employing our empirical model described above, we have investigated the financial impacts of both possible interpretations of this provision. Table 6 shows our estimation of the revenues generated from the auctioning of allowances in the year 2012 per EU Member State for the two different interpretations of Article $3 \mathrm{~d}$ under consideration. In addition, the delta in revenues (in million $€$ ) is presented.

Only a few EU Member States will generate considerably high amounts of revenues from the auctioning of 
Table 6 Auction revenues per EU member state

\begin{tabular}{|c|c|c|c|c|c|c|c|c|}
\hline \multirow[b]{2}{*}{$\begin{array}{l}\text { Administering } \\
\text { member state }\end{array}$} & \multicolumn{3}{|c|}{$\begin{array}{l}\text { Proportional allocation, according to attributable } \\
\text { aviation emissions in } 2010\end{array}$} & \multicolumn{3}{|c|}{$\begin{array}{l}\text { Allocation according to } 2010 \text { emissions of } \\
\text { administered airlines }\end{array}$} & \multicolumn{2}{|c|}{$\begin{array}{l}\text { Difference in auction } \\
\text { revenues in million } \\
\text { EUR per year }\end{array}$} \\
\hline & $\begin{array}{l}\text { Percentage } \\
\text { share of } \\
\text { attributable } \\
\mathrm{CO} 2 \\
\text { emissions in } \\
\mathrm{Mt}\end{array}$ & $\begin{array}{l}\text { Auction } \\
\text { revenues in } \\
\text { million EUR, } \\
25 \text { EUR per } \\
\text { ton }\end{array}$ & $\begin{array}{l}\text { Auction } \\
\text { revenues in } \\
\text { million EUR, } \\
40 \text { EUR per } \\
\text { ton }\end{array}$ & $\begin{array}{l}\text { Percentage } \\
\text { share of } \\
\mathrm{CO} 2 \\
\text { emissions } \\
\text { in Mt }\end{array}$ & $\begin{array}{l}\text { Auction } \\
\text { revenues in } \\
\text { million EUR, } \\
25 \text { EUR per } \\
\text { ton }\end{array}$ & $\begin{array}{l}\text { Auction } \\
\text { revenues in } \\
\text { million EUR, } \\
40 \text { EUR per } \\
\text { ton }\end{array}$ & $\begin{array}{l}25 \text { EUR } \\
\text { allowance } \\
\text { value }\end{array}$ & $\begin{array}{l}40 \text { EUR } \\
\text { allowance } \\
\text { value }\end{array}$ \\
\hline Austria & $1.5 \%$ & 10.1 & 16.2 & $1.2 \%$ & 7.8 & 12.4 & -2.4 & -3.8 \\
\hline Belgium & $2.5 \%$ & 16.8 & 26.8 & $1.6 \%$ & 10.6 & 17.0 & -6.2 & -9.9 \\
\hline Bulgaria & $0.2 \%$ & 1.2 & 1.9 & $0.3 \%$ & 1.7 & 2.7 & 0.5 & 0.8 \\
\hline Cyprus & $0.3 \%$ & 2.3 & 3.6 & $0.2 \%$ & 1.2 & 1.9 & -1.1 & -1.7 \\
\hline $\begin{array}{l}\text { Czech } \\
\text { Republic }\end{array}$ & $0.6 \%$ & 3.9 & 6.2 & $0.4 \%$ & 2.9 & 4.7 & -0.9 & -1.5 \\
\hline Denmark & $1.6 \%$ & 10.6 & 17.0 & $0.4 \%$ & 2.9 & 4.6 & -7.7 & -12.4 \\
\hline Estonia & $0.1 \%$ & 0.4 & 0.6 & $0.1 \%$ & 0.4 & 0.6 & 0.0 & 0.0 \\
\hline Finland & $1.2 \%$ & 7.8 & 12.4 & $1.3 \%$ & 8.4 & 13.5 & 0.7 & 1.1 \\
\hline France & $14.6 \%$ & 97.5 & 155.9 & $12.3 \%$ & 82.3 & 131.6 & -15.2 & -24.3 \\
\hline Germany & $18.7 \%$ & 124.7 & 199.5 & $20.1 \%$ & 134.2 & 214.8 & 9.6 & 15.3 \\
\hline Greece & $1.3 \%$ & 8.8 & 14.1 & $0.7 \%$ & 4.6 & 7.4 & -4.2 & -6.7 \\
\hline Hungary & $0.5 \%$ & 3.1 & 5.0 & $0.6 \%$ & 4.0 & 6.4 & 0.8 & 1.3 \\
\hline Ireland & $1.3 \%$ & 8.7 & 13.9 & $3.1 \%$ & 20.9 & 33.4 & 12.2 & 19.5 \\
\hline Italy & $7.6 \%$ & 50.9 & 81.5 & $4.4 \%$ & 29.4 & 47.0 & -21.6 & -34.5 \\
\hline Latvia & $0.2 \%$ & 1.1 & 1.7 & $0.2 \%$ & 1.3 & 2.1 & 0.2 & 0.4 \\
\hline Lithuania & $0.1 \%$ & 0.6 & 1.0 & $0.1 \%$ & 0.4 & 0.7 & -0.2 & -0.3 \\
\hline Luxemburg & $0.8 \%$ & 5.5 & 8.8 & $0.8 \%$ & 5.1 & 8.1 & -0.5 & -0.7 \\
\hline Malta & $0.1 \%$ & 0.8 & 1.2 & $0.1 \%$ & 0.9 & 1.4 & 0.1 & 0.2 \\
\hline Netherlands & $8.1 \%$ & 54.2 & 86.7 & $7.5 \%$ & 50.1 & 80.2 & -4.1 & -6.5 \\
\hline Poland & $0.9 \%$ & 5.8 & 9.3 & $0.6 \%$ & 4.0 & 6.3 & -1.8 & -2.9 \\
\hline Portugal & $1.8 \%$ & 11.7 & 18.7 & $1.6 \%$ & 11.0 & 17.6 & -0.7 & -1.1 \\
\hline Romania & $0.4 \%$ & 2.4 & 3.9 & $0.3 \%$ & 1.7 & 2.7 & -0.7 & -1.2 \\
\hline Slovakia & $0.1 \%$ & 0.5 & 0.9 & $0.2 \%$ & 1.4 & 2.2 & 0.8 & 1.3 \\
\hline Slovenia & $0.1 \%$ & 0.4 & 0.6 & $0.1 \%$ & 0.4 & 0.7 & 0.0 & 0.0 \\
\hline Spain & $9.1 \%$ & 60.6 & 97.0 & $6.3 \%$ & 42.1 & 67.3 & -18.6 & -29.7 \\
\hline Sweden & $1.5 \%$ & 10.0 & 16.0 & $1.9 \%$ & 12.9 & 20.6 & 2.9 & 4.6 \\
\hline \multirow{2}{*}{$\begin{array}{l}\text { United } \\
\text { Kingdom }\end{array}$} & $25.5 \%$ & 166.5 & 266.4 & $33.7 \%$ & 224.5 & 359.3 & 58.1 & 92.9 \\
\hline & $100.0 \%$ & 666.9 & 1067.1 & $100.0 \%$ & 666.9 & 1067.1 & & \\
\hline
\end{tabular}

DLR model results

allowances: United Kingdom, Germany, France, The Netherlands, Spain and Italy. These EU States will receive between 224.5 million $€$ (UK) and 29.4 million $€$ (I) under the assumption of an allowance price of $25 €$ per $t$ of $\mathrm{CO}_{2}$, and between 359.5 million $€$ (UK) and 47 million $€$ (I) with an assumed allowance price of $40 €$ per $\mathrm{t} / \mathrm{CO}_{2}$ in the year 2012. Consequently, United Kingdom, Germany, France, The Netherlands, Spain and Italy will receive more than two thirds of the total revenues from the auctioning of allowances while the remaining $22 \mathrm{EU}$ Member States will gain less than one third combined. (Fig. 2)
This can firstly be explained by the fact that some of the biggest airlines of the world operate under a license granted by one of these Member States mentioned above, e. g., British Airways, Lufthansa, Air France/KLM, etc. Secondly, due to the relatively high number of scheduled flights served within as well as to and from these EU Member States, especially to and from intercontinental destinations, the amount of attributed emissions is remarkably bigger compared to those of the remaining Member States.

As shown in the table above, both UK and Germany will benefit to a large extent from the interpretation (of 
Share of auction revenues according to 2010 attributable emissions

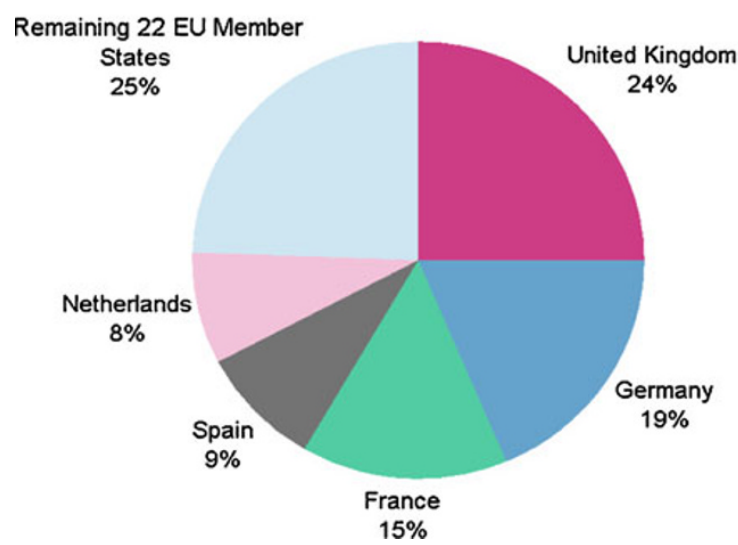

Share of auction revenues, according

to emissions by administered airlines

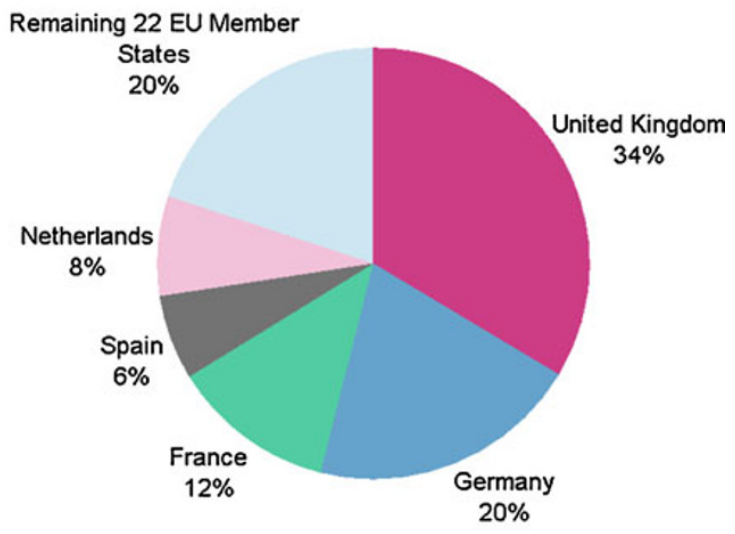

Source: DLR model results

Fig. 2 Share of auction revenues for EU member states by allocation mechanism. Source: DLR model results

Article 3d) that allowances will be auctioned according to the emissions share of the administered airlines. This could be justified by the fact that both countries administer most large network carriers, particularly those from non-EU countries, and will have to bear a relatively high administrative burden. However, given that air transport markets are widely liberalised and at least for intra-European flights of Community carriers the nationality does not matter any more, such an interpretation seems to be problematic from an equity point of view. Therefore a very thorough interpretation of Article $3 \mathrm{~d}$ is highly recommendable.

\section{Conclusion}

From 2012 onwards, the EU emissions trading system will be applied to the aviation sector and cover virtually all flights departing or arriving in the EU. The initial allocation of emission allowances to airlines will be based on a benchmark which is calculated by dividing historical $\mathrm{CO}_{2}$-emissions of the airlines participating in the scheme by their transport performance (expressed in revenue tonne-kilometres) of the year 2010. In this paper, we have applied a DLR-developed simulation model. This model is one of the first of its kind capable of simulating the future development of the aviation sector. In particular, it allows for the estimation of the economic impact of the EU-ETS on both the aviation sector in total and on selected groups of airlines. The five main results of our analysis can be summarised as follows:

First, if the EU will be successful in integrating non-EU carriers into the EU-ETS as planned today, a relatively ambitious $\mathrm{CO}_{2}$ control will be possible: Our results show that roughly one third of global aviation's $\mathrm{CO}_{2}$-emissions will be subject to the new regulation.

Second, the benchmark, which is the basis of the initial allocation of allowances to aircraft operators, is estimated by our model at $0.60 \mathrm{~kg} \mathrm{CO}_{2}$ per RTK. Apart from very few exceptions, virtually all passenger airlines will need to purchase additional $\mathrm{CO}_{2}$ allowances for their operations in 2012 and beyond. On average, carriers operating from and to EU airports will have to purchase allowances for about one third of their emissions in 2012.

Third, based on the estimated range of future allowance prices $\left(25-40 €\right.$ per ton of $\left.\mathrm{CO}_{2}\right)$, the total cost for the aviation sector is expected to be in the range between 1.9 and 3.0 billion $€$ in the year 2012 alone. As the potential for endogenous emission reduction in the aviation sector is rather low, the airlines will have to buy allowances for about 48.1 million tonnes of $\mathrm{CO}_{2}$ from stationary sources taking part in the EU-ETS.

Fourth, a more detailed analysis of selected airline groups reveals that resulting from the EU-ETS, European network carriers will be affected by a competitive disadvantage compared to non-EU airlines. For EU-based carriers, the percentage of freely allocated allowances compared to the total allowances required will remain below the corresponding level for non-EU carriers. This is because the former operate their feeder network with relatively high specific emissions under the ETS, while the latter operate only long-haul flights to and from Europe. This implies a systematic cost disadvantage for European network operators.

Fifth, our estimations of the revenues generated from the auctioning of allowances show that only a few EU Member States will generate considerably high amounts: United Kingdom, Germany, France, The Netherlands, Spain and 
Italy. Due to different possible interpretations of the rules concerning the auctioning of allowances, some EU States may profit more than others. Therefore, a very thorough interpretation of these rules is highly recommendable.

Finally, it becomes evident that the integration of aviation into emission trading schemes is a particularly difficult challenge both from an environmental economics and political standpoint. To jeopardize matters, emissions trading systems designed fundamentally different will be introduced globally within the next $5-10$ years with some of them being already in force (New Zealand, e. g.). Linking the EU trading scheme with these systems will be technically complex and may lead to competitive distortions within the aviation sector. Therefore a global system or an international harmonized approach for the limitation of aviation's $\mathrm{CO}_{2}$ emissions would be the best solution.

\section{Copyright notice/Disclaimer}

Produced with the EUROCONTROL Base of Aircraft Data (BADA). BADA is a tool owned by EUROCONTROL (C)2006 All rights reserved

Aircraft performance data contained herein are based on data drawn from the EUROCONTROL Base of Aircraft Data (BADA). It is to be noted that the aircraft performance models and data contained in BADA have been developed by EUROCONTROL from a set of aircraft operational conditions available to EUROCONTROL. EUROCONTROL has validated BADA aircraft models only for those conditions and can therefore not guarantee the model's accuracy for operating conditions other then the reference conditions.

Open Access This article is distributed under the terms of the Creative Commons Attribution Noncommercial License which permits any noncommercial use, distribution, and reproduction in any medium, provided the original author(s) and source are credited.

\section{References}

1. Airbus (2007) Global market forecast, Blagnac Cedex 2007

2. Air Transport Association (2009): Annual traffic and ops: World Airlines; http://www.airlines.org/economics/traffic/World+Airline +Traffic.htm; retrieved April 1st 2009

3. Boeing (2008) Current market outlook 2008-2027, Seattle 2008

4. Anger A, Köhler J (2010) Including aviation emissions in the EUETS: much ado about nothing. Transp Policy 17:38-46

5. Boon B, Davidson M, Faber J, van Velzen A (2007) Allocation of allowances for aviation in the EU ETS: The impact on the profitability of the aviation sector under high levels of auctioning, Final report, Delft

6. Commission of the European Communities (2006) Summary of the impact assessment; Inclusion of aviation in the EU greenhouse gas emissions trading scheme, SEC (2006) 1685, Brussels

7. Commission of the European Communities (2009) Commission Regulation (EC) No 748/2009 of 5 August 2009 on the list of aircraft operators which performed an aviation activity listed in
Annex I to Directive 2003/87/EC on or after January 12006 specifying the administering Member State for each aircraft operator, in: Official Journal of the European Union L219/1, Brussels, 22 August 2009

8. Council of the European Union (2009) Proposal for a directive of the European parliament and of the council amending directive 2003/87/ EC so as to improve and extend the greenhouse gas emission allowance trading system of the Community, 5862/08, Brussels, 29 January 2008

9. Council of the European Union (2009) Directive 2008/101/EC of the European Parliament and the Council of 19 November 2008 amending Directive 2003/87/EC so as to include aviation activities in the scheme for greenhouse gas emission allowance trading within the Community, in: Official Journal of the European Union L 8/3, Brussels, 13 January 2009

10. EUROCONTROL (2004) User Manual for the Base of Aircraft Data (BADA) - Revision 3.6, ECC Note No. 10/04, Bretigny

11. EUROSTAT (2009) EUROSTAT data; http://epp.eurostat.ec.europa. eu/portal/page/portal/transport/data/database; retrieved April 1st, 2009

12. Federal Aviation Administration (2005) SAGE-System for assessing Aviation's Global Emissions, Version 1.5, Technical Manual, FAA-EE-2005-01

13. Faber J, van de Vreede G, Lee DS (2007) The impacts of the use of different benchmarking, methodologies on the initial allocation of emission trading scheme permits to airlines, Delft

14. Forsyth P (2008) The impact of climate change policy on competition in the air transport industry, joint transport research centre discussion paper no. 2008-18, prepared for the Round Table of 2-3 October 2008 on Airline Competition, Systems of Airports and Intermodal Connections at the OECD in Paris, Clayton, Australia

15. Forsyth P, Dwyer L, Spurr R (2007) Climate change policies and Australian tourism: A scoping study of the economic aspects. STCRC Centre for Tourism Economics and Policy Research, Clayton

16. IATA (2004) Environmental review 2004. Montreal, Geneva

17. ICAO (2008) Annual report of the council 2007, Doc 9898, Montreal 2008

18. ICAO (2008) Committee on aviation environmental protection (CAEP), Steering Group Meeting, Seattle, 22 to 26 September 2008, FESG CAEP/8 Traffic and fleet forecasts, Document CAEP-SG/2/20082-IP/08

19. ICAO (2009) ICAO data; http://www.icaodata.com; retrieved April 1st 2009

20. ICF (2006) Including Aviation into the EU ETS: Impact on EU allowance prices, Final report on behalf of the UK Department for Environment, Food \& Rural Affairs and the UK Department for Transport, London

21. Lewis M, Curien I (2008) It takes CO2 (Carbon Dioxide) to Contango. Research Report of Deutsche Bank. Fulton, London

22. New Carbon Finance (2008) Easy carbon credits coming to an end; http://www.newcarbonfinance.com/pdf/2008-07-29_PR_Car bon_Credits.pdf;retrieved September 1st, 2008

23. OAG Aviation Solutions (2004-2008) OAG MAX flight schedules on CD-ROM, monthly editions for the years 20042008

24. Rolls Royce (2007) Market outlook 2007, Derby

25. Scheelhaase J, Grimme W, Schaefer M (2010) The inclusion of aviation into the EU emission trading scheme-impacts on competition between European and non-European network airlines. Transp Res D 15:14-25

26. UBS (2007) UBS raises EUA price forecast to $35 €$; http://www. globalcarbonexchange.com/latest-industry-news/ubs-raises-euaprice-forecast-to-35-euros.html; November 14th, 2007; retrieved September 1st 